RESEARCH ARTICLE

\title{
Bambusa bambos (L.) Voss. alters Structure and composition of native forests: A study from moist evergreen forests in Sri Lanka
}

\author{
M.P.T. Wijewickrama ${ }^{1, *}$, W.A.I.P. Karunaratne ${ }^{2}$, D.S.A. Wijesundara ${ }^{3}$ and H.M.S.P. Madawala ${ }^{4}$ \\ ${ }^{1}$ Postgraduate Institute of Science, University of Peradeniya, Peradeniya, Sri Lanka. \\ ${ }^{2}$ Department of Zoology, Faculty of Science, University of Peradeniya, Peradeniya, Sri Lanka. \\ ${ }^{3}$ National Institute of Fundamental Studies, Hantana Road, Kandy, Sri Lanka. \\ ${ }^{4}$ Department of Botany, Faculty of Science, University of Peradeniya, Peradeniya, Sri Lanka.
}

Received: 18/10/2019 ; Accepted: 20/04/2020

\begin{abstract}
Studies to evaluate consequences of native species showing invasive behaviour are rather scarce in the tropics. Bambusa bambos (L.) Voss., a native bamboo species, expands populations in its native range causing changes to the appearance of forests in dry and intermediate zones of Sri Lanka. The study evaluated the impacts of $B$. bambos spread in Tropical Moist Evergreen Forests (TMEFs) in Sri Lanka. A vegetation study was carried out in forest patches with and without bamboo $(\mathrm{B}+$ and B-) from three study sites viz., Galboda (GAL), Moragolla (MOR) and Maragomuwa (MAR) located in the Intermediate Zone of the island. Six $100 \mathrm{~m}^{2}$ quadrats were eramarked at different distances from the forest edge towards the forest interior along three transects in each $\mathrm{B}+$ and $\mathrm{B}$ - forest communities per site totaling 108 quadrats $(2$ forest communities $\mathrm{B}+$ and $\mathrm{B}-\times 3$ transects $\times 6$ distances $\times 3$ sites $=108$ ). Due to high site-specific differences, the results were analyzed and presented site-wise. Of the total of 127 species, $35(27.6 \%)$ and $20(15.7 \%)$ species were exclusively found in $\mathrm{B}+$ and $\mathrm{B}-$, respectively. The endemics were constantly more abundant in bamboo-free forest patches. The analyses also revealed a high dissimilarity of species compositions between $\mathrm{B}+$ and $\mathrm{B}-$ forest communities. The mortality incidences were significantly greater in bamboo-forests, possibly due to frequent fires aided by high accumulation of light bamboo litter. Despite no consistent differences between $\mathrm{B}+$ and $\mathrm{B}$ - communities in all study sites due to high heterogeneity, the results indicate that $B$. bambos has shown the potential to alter the composition and structure of these native forests through bamboo-driven modifications to micro-environmental conditions of these forests. Thus, the study highlights the importance of more comprehensive studies to explore long-term impacts of $B$. bambos in native forests in the region and to introduce measures to mitigate some of these negative impacts. The underlying causes of high mortality incidences should also be further investigated as it may leads to the decline of the quality of these native forests.
\end{abstract}

Keywords: over-dominance; tropical moist evergreen forests; Sri Lanka; Bambusa bambos; mortality

\section{INTRODUCTION}

The exotic invasive species are known to alter vegetation and ecosystem processes in their introduced habitats and had been widely studied under various soil-climatic conditions (Hulme, 2007; Richardson et al., 2000; Vila et al., 2009). In recent times, it was noted that even some native species are showing the ability to expand populations causing potentially negative impacts on their home range vegetation (Bai et al., 2016; Prematilleke et al., 2015). When native and/or endemic species expand their populations similar to their exotic counterparts, it is aptly coined as 'over-abundance' or 'over-dominance' rather than 'invasion' solely to evade any disputes in definitions (Garrot et al., 1993). Though ecological impacts of exotic invasive species are well known (Maranho and Salimon 2015), comparatively few studies have been conducted so far to evaluate potential impacts of native/endemic species displaying invasive behavior (Carey et al., 2012; Valery et al., 2013). Thus, scientists have highlighted the importance of gathering information on potential weedy species in native ranges as this information can be useful in introducing effective management interventions to rehabilitate affected ecosystems (Hufbauer and Torchin 2008).

There is growing number of studies in the northeast Asian region exploring potential impacts of expanding populations of native bamboo species in their home ranges (Lima et al., 2012; Canavan et al., 2017). Bamboos are known to become weedy in both their native and introduced habitats and the threats are almost similar irrespective of their status of origin (native or exotic) (Canavan et al., 2019). Due to their inherently rapid growth, bamboos are generally considered as pioneers in forest successions (Larpkern, 2005), and at the same time recognize them as perpetrators of arresting the natural succession (Griscom and Ashton, 2013). The bamboos often display superior growth over their native counterparts due to their inherent traits such as the production of ample amount of seeds, rapid clonal growth (Lima et al., 2012) and high competition for limited resources (nutrients and water). These traits help 
bamboos to thrive under challenging conditions, ultimately triggering population expansions once the conditions altered as a result of natural and human-induced activities (Canavan et al., 2017). Despite the reputation as one of the plant groups with highly 'invasive' species, there is a dearth of information on ecological impacts on their native vegetation (Buckingham et al., 2011; Space and Flynn 2000), especially in forest ecosystems (Levine et al., 2004).

According to studies, bamboos have shown tendencies to alter the structure and function of native vegetation through competitive exclusion of other co-occurring native species (Dutta and Reddy 2016; Kobayashi et al., 2015; Kudo et al., 2011; Lima et al., 2012; Rother et al., 2016; Suzuki, 2015; Tokuoka et al., 2015; Yang et al., 2015). Bamboos also inflict physical damages to the forest canopy potentially ensuing tree mortality, reducing basal area and hindering seedling recruitment (Griscom and Ashton, 2006). Vegetation losses are also reported due to wild fires facilitated by high accumulation of litter following synchronous flowering and death cycles in bamboo (Rayle et al., 2015). While some studies conclude that the higher abundance of bamboos may decrease species richness (Castro et al., 2013), others demonstrate their facilitative role in increasing the same (Silveira, 1999). The low tree densities reported in bamboo-dominated forests have been attributed to seed limitations following the over-dominance of a single species (Rother et al., 2009).

Bambusa bambos (L.) Voss. is a native of south and south-east Asia with a wide distribution in the tropics. Bambusa has also been identified as one of the genera that contain most of the listed invasive species (Canavan et al., 2016). It prefers a humid tropical climate with a low to moderate elevation $(<$ than $1,000 \mathrm{~m}$ ) and a rainfall of 2,000 - 2,500 mm (Sarojam and Kumar, 2001). In Sri Lanka, its distribution has stretched from the Intermediate Zone to the immediate margins of the Dry Zone of the island, particularly creating a patchy distribution with an affinity to alter the structure and composition of native forests (Figure 1).

Bambusa bambos are known to spread and form monoculture stands in disturbed sites, along river banks and roadsides, due to highly active clonal production (CABI, 2020). Due to its ability to expand rapidly (Duriyaprapan and Jansen, 1995; Ohrnberger, 1999), B. bambos can be identified as problematic plant with an invasive nature. In Cuba, it is already identified as an invasive species and scored a higher value for invasiveness following a risk assessment study in Florida, USA (IFAS 2014). Despite its patchy distribution in dry and intermediate zone forests in Sri Lanka, B. bambos cannot be identified as an 'invasive' due to its mismatch in the definition. However, the expansion of $B$. bambos seems to alter the vegetation structure and species composition by out-competing the typical forest species in tropical moist semi-evergreen forests in Sri Lanka (Gunatilleke et al., 2008), suggesting a looming threat unless measures taken to curb its further expansion.

\section{MATERIALS AND METHODS}

\section{Study Area}

The study was conducted in Tropical Moist Evergreen forests (TMEFs) located along the northern borders of the Central Province of Sri Lanka, which belonged to the northern intermediate floristic region of the island (Ashton and Gunatilleke, 1987). The TMEF is the major forest type in the Intermediate Zone of the island, and are dominated by Mangifera zeylanica, Canarium zeylanicum, Filicium decipiens, Dimorcarpus longan, Nothopegia beddomei and Gironniera parvifolia. Anacardiaceae, Sapindaceae, Euphorbiaceae and Moraceae are the most dominant families (Gunatilleke et al., 2008). The three strata identified in TMEFs include the canopy (20 - $25 \mathrm{~m})$, subcanopy/shrub layer $(5-10 \mathrm{~m})$, and the ground vegetation. The mature forests show more or less a continuous canopy with relatively sparse ground vegetation. The mean annual temperature in the Intermediate Zone is in the range of $22.5^{\circ}-25.0^{\circ} \mathrm{C}$ with an annual rainfall of 2,000 - 2,500 $\mathrm{mm}$. The area receives rainfall mainly from the northeast monsoons, with an extended dry period from April to September (Somasekeram, 1988). The topography of the area is classified as flat to gentle slopes. The landscape features in the area are markedly influenced by the Knuckles Mountain Range (IUCN, 2007). The geology of the area is of Highland Series from the pre Cambrian era. Reddish brown earths and immature brown loams are the major soil types along with erosional remnants (Somasekaram, 1988; Panabokke, 1996).

\section{Study sites}

Three representative forest patches with bamboo $(\mathrm{B}+)$ were selected from three different locations in close proximity viz., Galboda (GAL), Moragolla (MOR) and Maragomuwa (MAR). The study sites are situated approximately $2-6 \mathrm{~km}$ apart from each other (Figure 2). Three comparable forest patches without bamboo (B-) were also selected from respective locations for comparison. The three study sites are come under two forest reserves viz., Elagomuwa forest reserve (Galboda and Moragolla) and Kumaragala forest reserve (Maragomuwa).

\section{Experimental design}

In each bamboo (B+) and non-bamboo (B-) forest patches, three $110 \mathrm{~m}$ long transects were laid approximately parallel to each other ( $20 \mathrm{~m}$ apart), starting from the edge of the forest towards the forest interior. GAL and MOR sites are bordered by a derelict tarred road leading to a small hamlet while the MAR site is bordered by home gardens and a transmission line corridor. Along each transect, six $10 \mathrm{~m}$ $\times 10 \mathrm{~m}$ quadrats were established at different distances starting from the edge $(0 \mathrm{~m})$ towards the forest interior $(20$, $40,60,80$ and $100 \mathrm{~m}$ ), totaling 36 quadrats in each study site. 


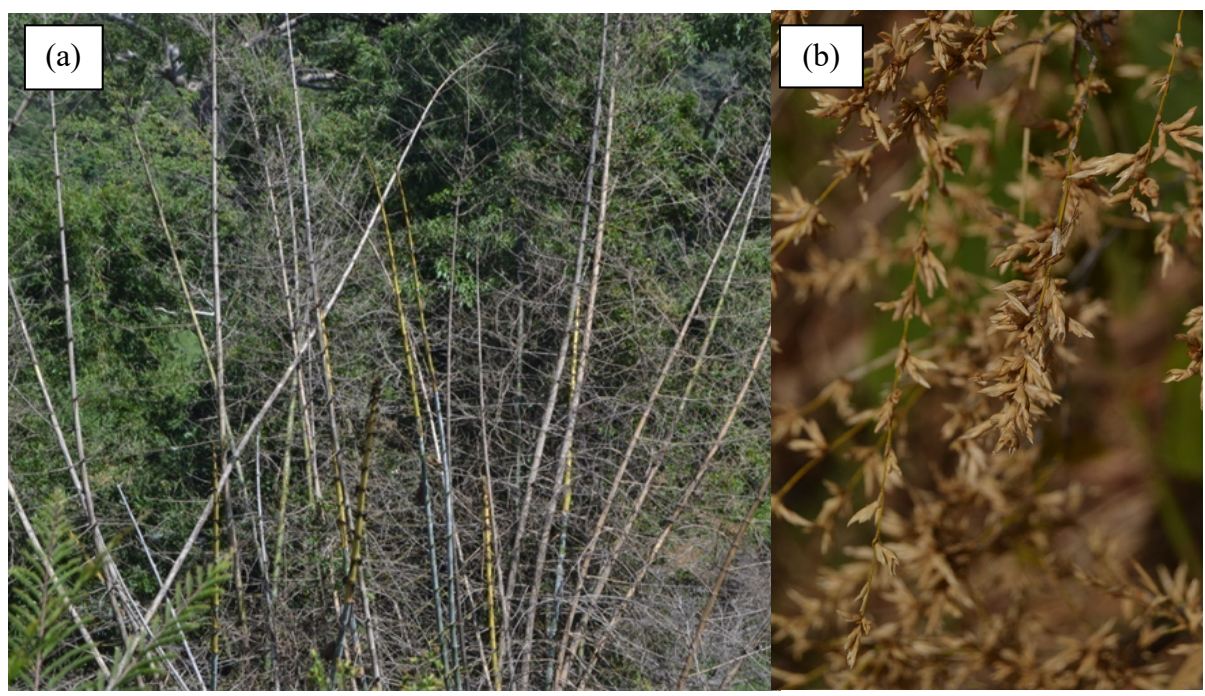

Figure 1: (a): The habit of native Bambusa bambos in moist evergreen forests in Sri Lanka; (b): Flowering of B. bambos.

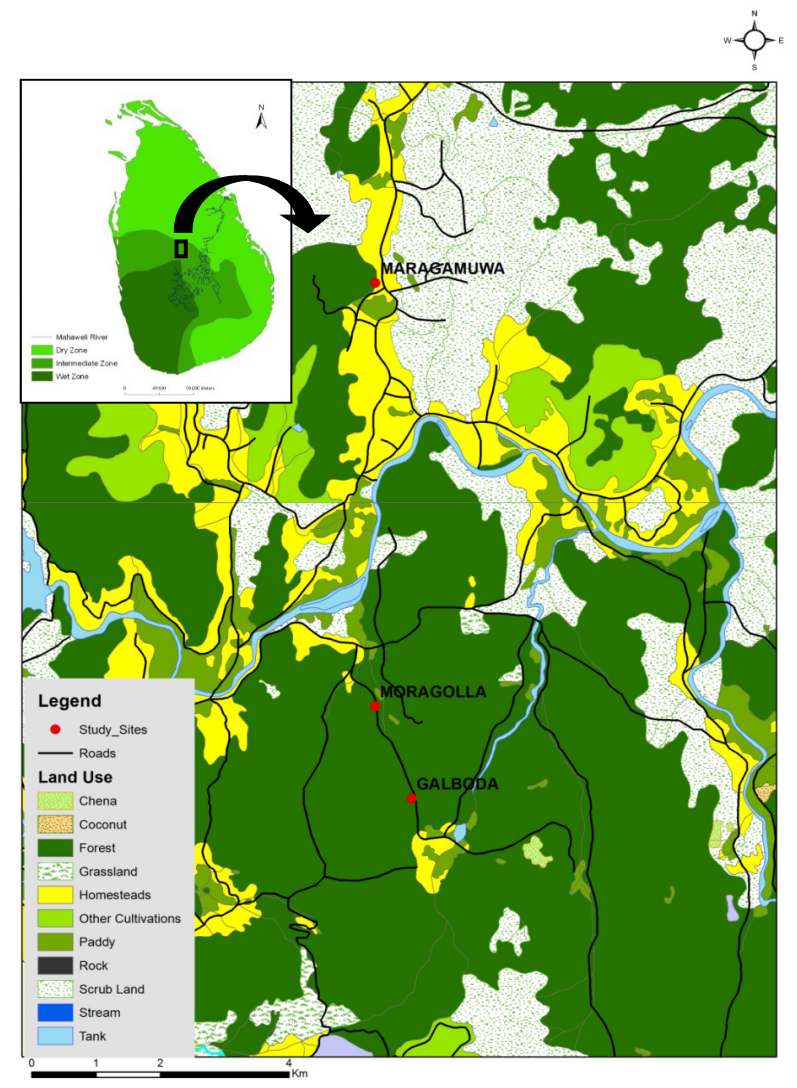

Figure 2: A land use map showing locations of the three study sites, Galboda (GAL), Moragolla (MOR) and Maragomuwa (MAR) in the Central Province of Sri Lanka.

\section{Vegetation sampling}

All individuals more than $2 \mathrm{~m}$ in height were enumerated and identified to their lowest taxonomic ranks using taxonomic guides and voucher specimens kept at the National Herbarium, Royal Botanic Gardens, Peradeniya, Sri Lanka. Completely and/or partially dead individuals were recorded based on visual evidences. The field sampling was started soon after the onset of north-east monsoons in January, 2017 and completed in April in the same year.

\section{Data Analysis}

The species accumulation curves were prepared and the diversity indices (Simpson, Shannon-Weiner, Evenness, Menhinick and Fisher's alpha) were calculated using PAST software (version 3.16). The density and species richness of different life forms (trees, shrubs and lianas), conservation status (endemic, native and exotic) and density of completely and/or partially dead individuals (mortality) were compared between $\mathrm{B}+$ and $\mathrm{B}$ - forest patches across the three study locations (GAL, MOR and 
MAR) and distances (0, 20, 40, 60, 80 and $100 \mathrm{~m})$ using General Linear Model in Minitab (Version 17.0, Statistical Software, 2010 by Minitab), followed by Tukey's pair wise mean comparisons. Prior to the analysis using GLM, the data set was tested for the normality of distribution. As there were significant differences between study sites, the results were re-analyzed and presented separately.

The culm densities of bamboo between distances were compared using one way ANOVA. The relative abundance and frequency of most dominant species were calculated and were compared between $\mathrm{B}+$ and $\mathrm{B}$ - using the Correspondence Analysis (CA) in Canoco 5.0 software. The dissimilarity between $\mathrm{B}+$ and $\mathrm{B}$-forest patches was also tested using SIMPER in PAST Software (version 3.16). Girth class distribution graphs were prepared for individuals with above $10 \mathrm{~cm}$ of diameter at breast height (DBH).

\section{RESULTS}

\section{Vegetation characteristics}

The study recorded a total of 127 species belonging to 103 genera and 47 families, of which 69 tree species, 28 shrubs and 30 woody climbers. The abundance, richness and stem density values were higher in MAR compared to GAL and MOR, regardless of the presence/absence of $B$. bambos (Table 1). Of the 127 species recorded, 35 species were found exclusively in $\mathrm{B}+$ forest patches $(\sim 28 \%)$ while 20 species were recorded exclusively in B- forests $(\sim 16 \%)$. Seventy two species $(\sim 57 \%)$ were shared by both B+ and B- sites. The number of exclusives was higher in bamboo forests in MOR and MAR (Table 1).

However, the abundance of endemic species was consistently higher in non-bamboo (B-) over bamboo forests $(\mathrm{B}+)$. The exotics were noticeably in low abundance in all study sites (Table 1).

\section{From forest edge to the interior}

The culm density of $B$. bambos, density and richness of trees and shrubs showed no consistent trends over distances from the forest edge towards the forest interior in both $\mathrm{B}+$ and B- communities.

\section{Bamboo versus non-bamboo}

\section{Density and richness}

The density and richness of trees, shrubs and lianas showed site-specific differences rather than consistent differences between $\mathrm{B}+$ and $\mathrm{B}-$. At MOR, the tree and shrub densities were significantly higher in $\mathrm{B}-$ than in $\mathrm{B}+$. At MAR, the liana density and richness was significantly higher in nonbamboo than in bamboo forests (Table 2).

\section{Mortality}

The density of completely and/or partially dead individuals was significantly higher in bamboo forests than in bamboofree forests in all three locations (Table 1). However, the mortality incidences were more striking at GAL and MAR in comparison to MOR.

\section{Species Accumulation Curves}

Species accumulation curves of bamboo forests are steeper than those of bamboo-free forests. Also, the species accumulation curves indicate more species in MAR than in other two locations (GAL and MOR) irrespective of the bamboo spread (Figure 3).

\section{Diversity and Similarity Indices}

Vegetation indices indicated that bamboo forests $(\mathrm{B}+)$ are more diverse than that of non-bamboo forests (B-) at MOR and MAR. The similarity indices showed values less than $50 \%$ in all study sites indicating relatively low similarity between the two forest communities (Table 1). Correspondence Analysis (CA) too showed a negative correlation between $\mathrm{B}+$ and $\mathrm{B}$ - forest communities, further confirming compositional differences following the spread of bamboo. At Galboda, the B+ and B- forest communities showed more marked differences in composition in comparison to other two sites (Table 3; Figure 4).

\section{SIMPER analysis}

The SIMPER analysis provided relative contribution (as a $\%$ ) of species to the contrast between bamboo- and nonbamboo forest communities (Table 4). Seven species have contributed approximately to $50 \%$ of the total dissimilarity between the two forest communities at GAL and MOR, while 13 species contributed to the same at MAR. Among the seven species at GAL, Nothopegia beddomei and Alphonsea sclerocarpa were exclusively found in nonbamboo forests. At MOR, in addition to Nothopegia beddomei, Miliusa indica too was exclusively observed in bamboo-free forests. At MAR, Croton officinalis and Grewia damine were exclusive in bamboo-forest while Alphonsea sclerocarpa, Polyalthia coffeoides and Lepisanthes senegalensis were exclusively observed in nonbamboo forests. In addition, Pterospermum suberifolium has also contributed to the dissimilarity between bamboo and non-bamboo forest communities in all study locations.

\section{Girth class distribution}

The girth class distribution curves drawn for individuals with girth classes less than $30 \mathrm{~cm}$ were demonstrated typical inverse J-shaped curves in all study sites irrespective of the presence/absence of bamboos (Figure 5). However, the figures drawn for individuals belonged to higher girth classes $(30-50 \mathrm{~cm})$ showed more site-specific differences. 
Table 1: The vegetation characteristics of bamboo (B+) and non-bamboo (B-) stands in study locations, Galboda (GAL), Moragolla (MOR) and Maragomuwa (MAR).

\begin{tabular}{|c|c|c|c|c|c|c|}
\hline & \multicolumn{2}{|c|}{ GALBODA } & \multicolumn{2}{|c|}{ MORAGOLLA } & \multicolumn{2}{|c|}{ MARAGOMUWA } \\
\hline & B+ & B- & B+ & B- & B+ & B- \\
\hline Overall abundance & 494 & 532 & 336 & 469 & 919 & 809 \\
\hline Trees & 362 & 358 & 208 & 292 & 475 & 387 \\
\hline Shrub & 95 & 146 & 75 & 137 & 309 & 245 \\
\hline Liana & 37 & 28 & 53 & 40 & 135 & 177 \\
\hline Endemic & 10 & 25 & 17 & 19 & 41 & 58 \\
\hline Native & 471 & 502 & 315 & 446 & 875 & 739 \\
\hline Exotic & 4 & 0 & 0 & 0 & 1 & 1 \\
\hline Species Richness & \multicolumn{2}{|c|}{70} & \multicolumn{2}{|c|}{77} & \multicolumn{2}{|c|}{103} \\
\hline Trees & 27 & 33 & 31 & 31 & 37 & 31 \\
\hline Shrub & 13 & 9 & 11 & 9 & 23 & 14 \\
\hline Liana & 8 & 5 & 15 & 8 & 22 & 19 \\
\hline Endemic & 1 & 2 & 2 & 3 & 5 & 4 \\
\hline Native & 42 & 43 & 54 & 43 & 74 & 56 \\
\hline Exotic & 2 & 0 & 0 & 0 & 1 & 1 \\
\hline $\begin{array}{l}\text { "Density of Completely/ } \\
\text { partially dead individuals (per } \\
100 \text { sq. m) }\end{array}$ & $6.72^{\mathrm{a}}$ & $0.83^{b}$ & $2.83^{\mathrm{a}}$ & $1.13^{\mathrm{b}}$ & $6.72^{\mathrm{a}}$ & $3.00^{\mathrm{b}}$ \\
\hline Stem density (per ha) & 2,744 & 2,955 & 1,866 & 2,606 & 5,106 & 4,494 \\
\hline Number of exclusive species & 23 & 24 & 29 & 20 & 39 & 21 \\
\hline \multicolumn{7}{|l|}{ Diversity Indices } \\
\hline Simpson & 0.905 & 0.939 & 0.935 & 0.893 & 0.963 & 0.946 \\
\hline Shannon-Weiner & 2.93 & 3.08 & 3.25 & 2.84 & 3.73 & 3.36 \\
\hline Fisher alpha & 13.1 & 12.4 & 20.2 & 13.4 & 21.8 & 16.3 \\
\hline Evenness & 0.357 & 0.462 & 0.443 & 0.357 & 0.508 & 0.448 \\
\hline
\end{tabular}

Similarity Indices

$\begin{array}{rlrr}\text { Jaccard Index }\left(\beta_{\mathrm{j}}\right) & 34.3 & 36.4 & 41.7 \\ \beta_{\text {sim }} & 0.49 & 0.42 & 0.50\end{array}$

\#Density of completely/partially dead individuals, GLM: GAL, $\mathrm{F}=15.27, \mathrm{p}=0.001 ; \mathrm{MOR}, \mathrm{F}=7.61, \mathrm{p}=0.011 ; \mathrm{MAR}, \mathrm{F}=7.04, \mathrm{p}=$ 0.014).

Table 2: Mean density and richness (per 100 sq. m) of trees, shrubs and woody lianas in bamboo (B+) and non-bamboo (B-) forest patches at Galboda (GAL), Moragolla (MOR) and Maragomuwa (MAR), Sri Lanka.

\begin{tabular}{|c|c|c|c|c|c|c|c|c|c|}
\hline & \multicolumn{3}{|c|}{ GALBODA } & \multicolumn{3}{|c|}{ MORAGOLLA } & \multicolumn{3}{|c|}{ MARAGOMUWA } \\
\hline & B+ & B- & p-value & B+ & B- & p-value & B+ & B- & p-value \\
\hline \multicolumn{10}{|c|}{ Mean Density (per 100 sq. m) } \\
\hline Trees & 20.1 & 19.9 & $0.947^{\text {ns }}$ & 11.6 & 16.2 & $0.037^{*}$ & 26.4 & 21.5 & $0.168^{\mathrm{ns}}$ \\
\hline Shrubs & 5.3 & 8.1 & $0.153^{\text {ns }}$ & 4.2 & 7.6 & $0.012^{* *}$ & 17.2 & 13.6 & $0.221^{\mathrm{ns}}$ \\
\hline Lianas & 2.1 & 1.6 & $0.482^{\mathrm{ns}}$ & 2.9 & 2.2 & $0.376^{\mathrm{ns}}$ & 7.5 & 9.8 & $0.024^{*}$ \\
\hline Total & 27.4 & 29.6 & $0.296^{\mathrm{ns}}$ & 18.7 & 26.1 & $0.991^{\mathrm{ns}}$ & 51.1 & 44.9 & $0.089^{\text {ns }}$ \\
\hline \multicolumn{10}{|c|}{ Mean Richness (per 100 sq. m) } \\
\hline Trees & 6.3 & 7.4 & $0.113^{\text {ns }}$ & 4.7 & 6.2 & $0.026^{*}$ & 9.5 & 7.7 & $0.053^{*}$ \\
\hline Shrubs & 2.2 & 2.9 & $0.102^{\mathrm{ns}}$ & 2.1 & 2.8 & $0.078^{\mathrm{ns}}$ & 6.3 & 3.7 & $0.000^{* * *}$ \\
\hline Lianas & 1.3 & 0.9 & $0.233^{\mathrm{ns}}$ & 1.9 & 1.5 & $0.296^{\mathrm{ns}}$ & 4.4 & 5.5 & $0.044^{*}$ \\
\hline Total & 9.8 & 11.3 & $0.066^{\mathrm{ns}}$ & 8.8 & 10.5 & $0.951^{\mathrm{ns}}$ & 20.3 & 16.9 & $0.007^{* *}$ \\
\hline
\end{tabular}




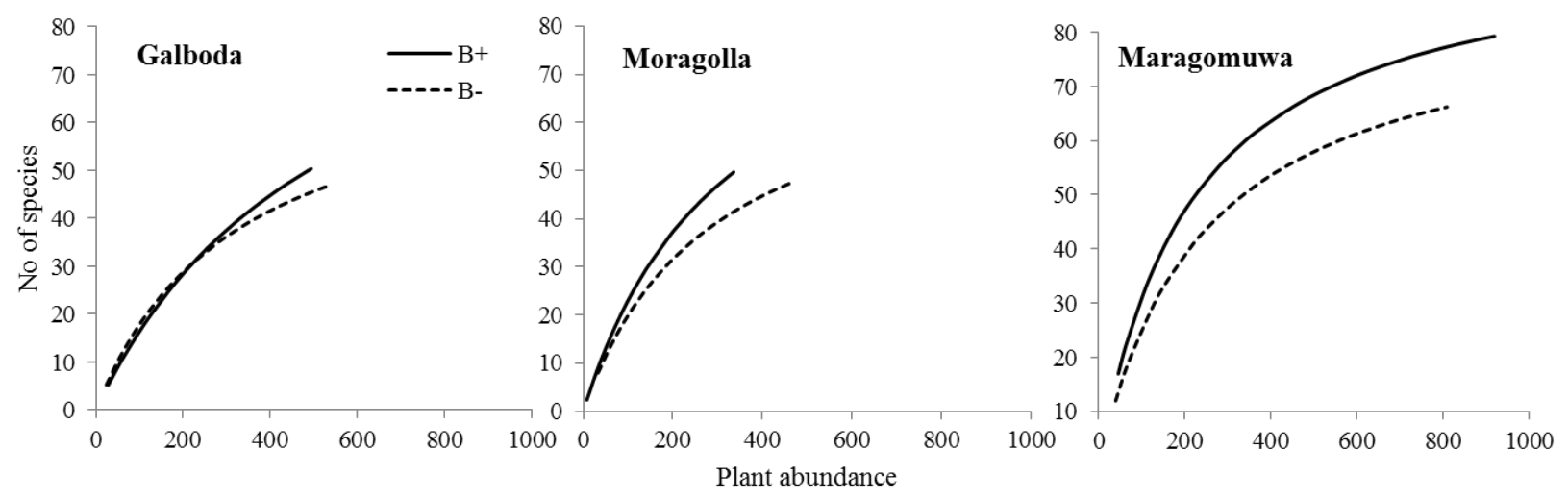

Figure 3: The species accumulation curves (with individuals above $2 \mathrm{~m}$ in height) between bamboo (B+) and non-bamboo (B-) forest communities at Galboda, Moragolla and Maragomuwa.

Table 3: Statistical details of Correspondence Analysis including the Eigen values and the cumulative variation between axes (as a percentage) for differences in species composition between $\mathrm{B}+$ and B- sites.

\begin{tabular}{lllll}
\hline Statistic & Axis 1 & Axis 2 & Axis 3 & Axis 4 \\
\hline Eigen values & 0.3320 & 0.2417 & 0.1906 & 0.1495 \\
\hline Explained variation (cumulative) & 32.51 & 56.18 & 74.85 & 89.49 \\
\hline
\end{tabular}
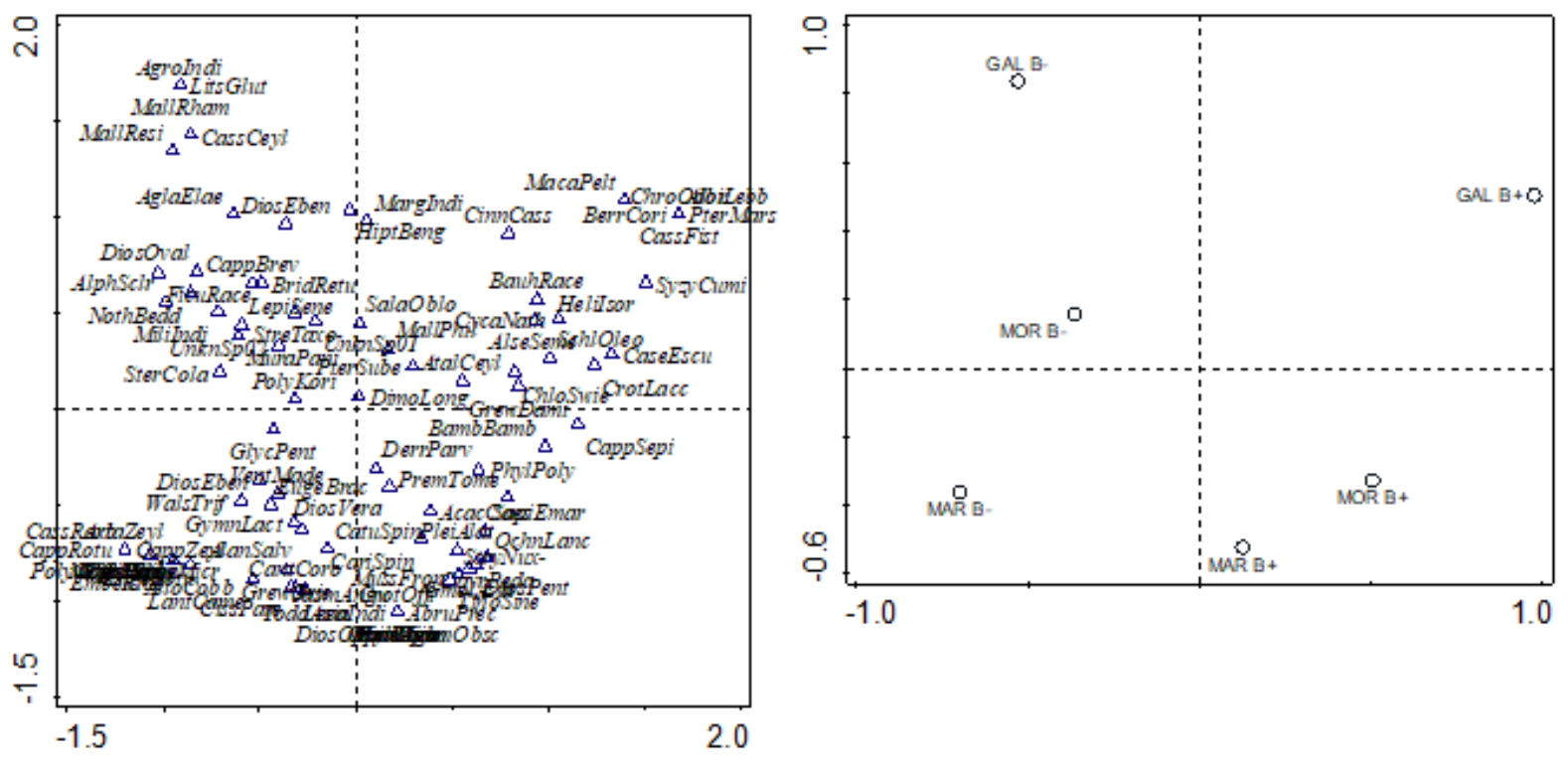

Figure 4: The ordination diagram following correspondence analysis (CA) of the relative abundance of species in B+ and B- forest patches in three different locations, GAL, MOR and MAR. The species names are abbreviated using the first four letters of the genus and the species names. 
Table 4: Overall average dissimilarity values and species contributed to approximately $50 \%$ of total dissimilarity between B+ and Bin GAL, MOR and MAR. Species in bold letters have contributed to the dissimilarity between B+ and B- in all three study locations.

\begin{tabular}{|c|c|c|c|c|c|c|}
\hline $\begin{array}{l}\text { Site/Overall Average } \\
\text { Dissimilarity }\end{array}$ & Species & $\begin{array}{l}\text { Aver. } \\
\text { Diss. }\end{array}$ & $\begin{array}{c}\text { Contrib. } \\
\quad \%\end{array}$ & $\begin{array}{c}\text { Cumulative } \\
\%\end{array}$ & $\begin{array}{c}\text { Mean } \\
\text { B+ }\end{array}$ & $\begin{array}{c}\text { Mean } \\
\text { B- }\end{array}$ \\
\hline \multirow{7}{*}{ Galboda/65.6 } & Pterospermum suberifolium & 8.35 & 12.7 & 12.7 & 23.3 & 6.58 \\
\hline & Macaranga peltata & 6.09 & 9.3 & 22.0 & 12.6 & 0.38 \\
\hline & Nothopegia beddomei & 4.98 & 7.6 & 29.6 & 0.00 & 9.96 \\
\hline & Alphonsea sclerocarpa & 4.23 & 6.5 & 36.1 & 0.00 & 8.46 \\
\hline & Streblus taxoides & 3.90 & 5.9 & 42.0 & 1.21 & 9.02 \\
\hline & Bambusa bambos & 2.93 & 4.5 & 46.5 & 5.87 & 0.00 \\
\hline & Capparis brevispina & 2.91 & 4.4 & 50.9 & 0.20 & 6.02 \\
\hline \multirow{7}{*}{ Moragolla/49.9 } & Glycosmis mauritiana & 6.57 & 13.2 & 13.2 & 3.27 & 16.4 \\
\hline & Bambusa bambos & 5.21 & 10.4 & 23.6 & 10.4 & 0.00 \\
\hline & Dimorphocalyx glabellus & 4.84 & 9.7 & 33.3 & 14.00 & 23.7 \\
\hline & Phyllanthus polyphyllus & 2.76 & 5.5 & 38.8 & 5.95 & 0.43 \\
\hline & Pterospermum suberifolium & 2.36 & 4.7 & 43.5 & 6.85 & 2.13 \\
\hline & Nothopegia beddomei & 2.03 & 4.1 & 47.5 & 0.00 & 4.05 \\
\hline & Miliusa indica & 1.81 & 3.6 & 51.2 & 0.00 & 3.62 \\
\hline \multirow{13}{*}{ Maragomuwa/50.7 } & Glycosmis mauritiana & 4.56 & 9.0 & 9.0 & 3.37 & 12.5 \\
\hline & Alphonsea sclerocarpa & 2.66 & 5.2 & 14.2 & 0.00 & 5.32 \\
\hline & Polyalthia korinti & 2.25 & 4.4 & 18.7 & 4.90 & 9.39 \\
\hline & Cipadessa baccifera & 2.24 & 4.4 & 23.1 & 5.22 & 0.74 \\
\hline & Lepisanthes tetraphylla & 2.16 & 4.3 & 27.4 & 4.57 & 0.25 \\
\hline & Pterospermum suberifolium & 1.97 & 3.9 & 31.2 & 6.53 & 2.60 \\
\hline & Croton officinalis & 1.63 & 3.2 & 34.5 & 3.26 & 0.00 \\
\hline & Bambusa bambos & 1.52 & 3.0 & 37.5 & 3.05 & 0.00 \\
\hline & Polyalthia coffeoides & 1.48 & 2.9 & 40.4 & 0.00 & 2.97 \\
\hline & Diospyros ebenum & 1.34 & 2.7 & 43.0 & 0.65 & 3.34 \\
\hline & Nothopegia beddomei & 1.31 & 2.6 & 45.6 & 0.22 & 2.84 \\
\hline & Pleiospermium alatum & 1.24 & 2.5 & 48.1 & 2.61 & 0.12 \\
\hline & Grewia damine & 1.03 & 2.0 & 50.1 & 2.07 & 0.00 \\
\hline
\end{tabular}



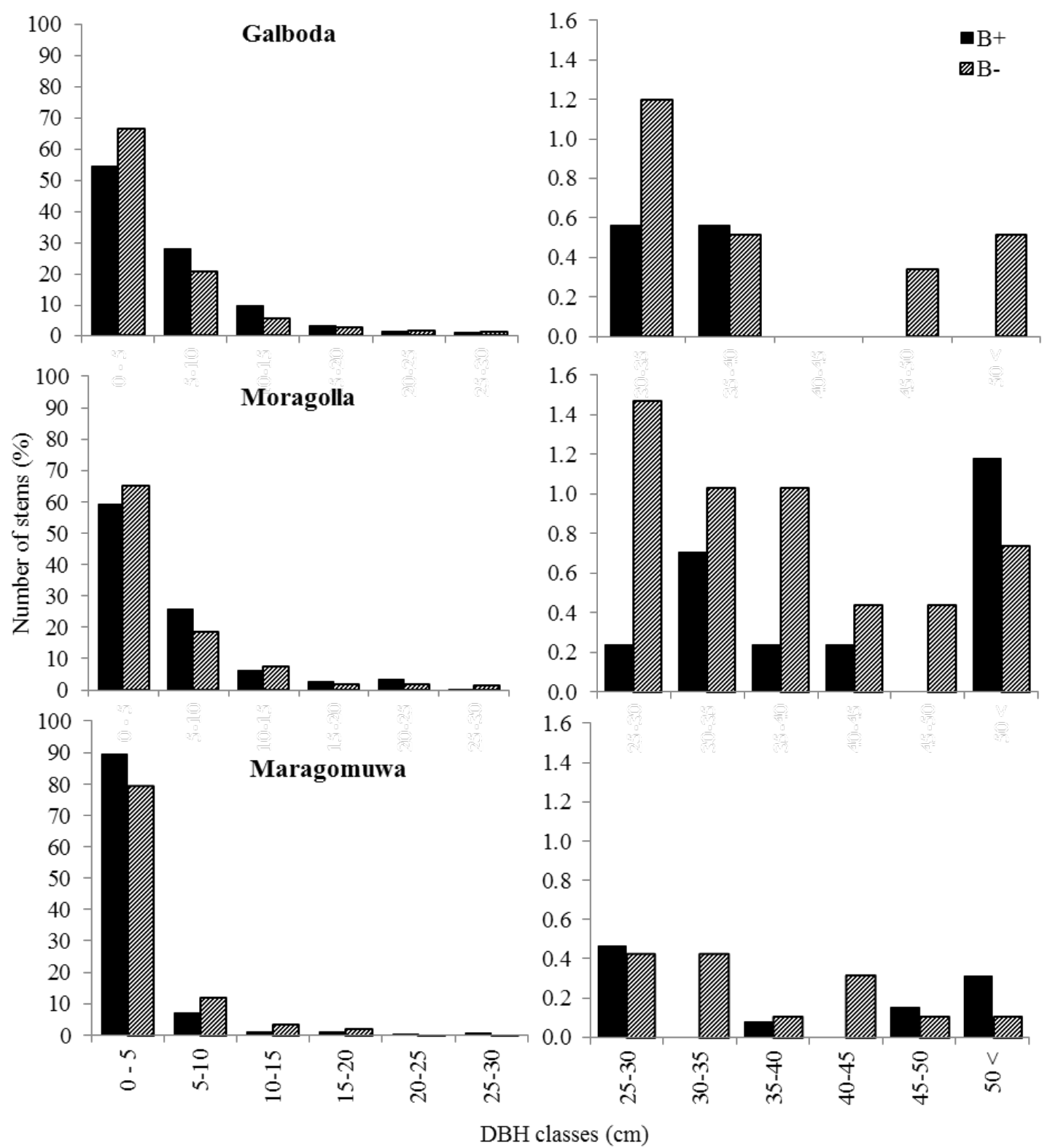

Figure 5: Distribution of percentage stem abundance of individuals above $2 \mathrm{~m}$ in height categorized under different DBH classes in $\mathrm{B}+$ and B- forest at Galboda, Moragolla and Maragomuwa. Graphs to the left-hand side include girth classes from 0-5 to 25-30 cm while on the right-hand side, girth classes from $30-35$ to $>50 \mathrm{~cm}$.

\section{DISCUSSION}

The overall results suggest that the prevalence of $B$. bambos seems to play a decisive role in altering the composition and structure of these secondary forests in the Intermediate Zone of Sri Lanka. However, the study also noted high heterogeneity among study sites despite their close proximity. The vegetation at MAR was denser and more diverse in comparison to GAL and MOR, possibly due to the specific locations of the latter two sites. The GAL and MOR sites are located in the immediate foothills of the Knuckles Mountain Range and situated relatively close proximity to each other $(\sim 2 \mathrm{~km})$, while MAR site is located somewhat away from the rest $(\sim 6 \mathrm{~km})$. The two sites (GAL and MOR) that are located closer to the mountainous range display a rockier and drier conditions than that of MAR. The existing vegetation at GAL and MOR is more or less sparse, and this sparseness is more conspicuous in bamboo forests $(\mathrm{B}+)$ than that of non-bamboo (B-) forests. Also, $B$. bambos showed somewhat a patchy distribution in GAL and MOR, while colonizing extensively along forest edges and on exposed rocky slopes. The bamboofree forest communities are more or less confined to the lower slopes that are less rocky. According to field evidences, MAR site has been occasionally disturbed by slash and burn agriculture despite its legal prohibition, due to its favorable landscape features in comparison to other two sites which are slopy and rocky in nature. The vegetation characteristics also indicate that MAR forest is relatively in its early successional stage in comparison to the other two sites. The bamboo spread mainly driven by past and present human-mediated disturbances together with other landscape features has transformed these forest communities into more heterogeneous in nature over time. 
Also, field observations suggest that grazing and trampling by wild animals are minimal except few occasional signs of trampled bamboo clumps by wild elephants roaming the area. The spiny nature of $B$. bambos restricts animal movements inside these bamboo-rich forests. As a result, bamboo-driven impacts are seemed to be shrouded by high site-specific differences between study locations. Despite high site-specific differences, both bamboo and non-bamboo forest communities are dominated by native species with relatively low prevalence of exotic species. The forests are generally known to be less susceptible to invasion by non-native species in comparison to most other habitats (Von Holle et al., 2003), though not spared by invasion of weedy native species such as B. bambos.

The B. bambos spread has incurred no significant and consistent impact on the density and richness of trees and shrubs, except few site-specific differences. However, the endemic species were constantly more abundant in bamboo-free forests, indicating their preference of conditions prevail in non-bamboo forests for establishment and survival. The lianas were constantly more abundant and rich in bamboo forests in GAL and MOR sites. Lianas are generally known to thrive under disturbed habitats due to their inherent ability to produce clonal stems in response to disturbances (Laurance 1998; Laurance et al., 2000; Ledo and Schnitzer 2014), proposing its role as an indicator plant in forest disturbances. In contrast, the liana density and richness was significantly higher in bamboofree forests at MAR, further confirming high site-specific differences among study sites. The overall results suggest that lianas are influenced by a combination of factors partly driven by the modifications due to the spread of $B$. bambos and other site-specific disturbances. The patchy distribution of B. bambos has often created discontinuous canopies in forest communities, allowing more sunlight to reach the ground layer. High sunlight that seeps into the forest floor favour the establishment of light-loving species including lianas. Due to the dense nature of the vegetation at MAR, the bamboo spread may not incur the same influence on the canopy as in other two study locations. The results also demonstrated that $\mathrm{B}+$ forests are more diverse than that of B- forests. The frequent canopy openings in bamboo forests seem to have provided suitable microsites in the forest floor to establish and grow light-loving species other than those confined to the forest undergrowth (Caccia et al., 2009; Kang et al., 2015; Wang and Liu, 2011), thus increasing the species diversity (Zhang et al., 2013).

SIMPER and CA analyses revealed compositional differences between bamboo- and non-bamboo forests further supporting bamboo-driven modifications to these native forests. Furthermore, the bamboo-rich forests always showed higherprevalence of exclusive species in comparison to non-bamboo forests. All exclusive species observed in bamboo-free forest communities that contributed highly to the dissimilarity between $\mathrm{B}+$ and $\mathrm{B}$ - forests, were shadeloving species. In contrast, the light-loving forest species such as Pterospermum suberifolium, Macaranga peltata, Cipadessa baccifera and Croton officinalis were recorded in higher abundance in bamboo forests. The shade-loving species viz., Nothopegia beddomei, Alphonsea sclerocarpa,
Glycosmis pentaphylla and Capparis brevispina were more prevalent in bamboo-free forests. In addition to B. bambos, $P$. suberifolium and $N$. beddomei have contributed markedly to the disparity between bamboo- and non-bamboo forests in all study sites. Higher prevalence of P. suberifolium in $\mathrm{B}+$ forests can also be considered as an evidence of past and present disturbances (Perera, 2012). Being one of the most dominant forest species in tropical moist evergreen forests in Sri Lanka (Gunatilleke et al., 2008), $N$. beddomei was recorded in higher abundance in bamboofree forests, while almost absent in $\mathrm{B}+$, suggesting its high vulnerability to disturbances driven by the spread of $B$. bambos. Previous studies too confirmed modifications to the species composition and community structure in forests following a bamboo spread (Gonzalez et al., 2002; Lima et al., 2012; Okutomi et al., 1996). Bamboos incur changes to the composition of forest communities through facilitating the establishment of rapid-growing early successional species in vacant locales created by dead individuals and canopy openings (Griscom and Ashton 2006; Oliveira 2000; Silveira 2005). The findings favour the intermediate disturbance hypothesis (IDH) where it describes maximum diversity at intermediate regimes of disturbances (Connell 1978; Molino and Sabatier 2001), though it has been refuted by some ecologists lately (Fox 2013).

A consistently higher prevalence of dead individuals (mainly trees and shrubs) were observed in bamboo forests in comparison to non-bamboo, indicating detrimental impacts of the bamboo spread on the survival of forest trees and shrubs. Previous studies too noted similar observations linked to over-dominance of bamboo species (Griscom and Ashton 2006; Lima et al., 2012; Medeiros et al., 2013). Studies have emphasized number of contributory factors to high mortality incidences following bamboo dominance in forests. Of them, allelo chemicals (Zhao et al., 2008), physical damages (Lima et al., 2012) and frequent fires enhanced by high litter inputs (Castro et al., 2013) have been identified as major driving forces behind high mortality incidences in bamboo forests. High mortality of trees and shrubs could also contributed to open canopy in bamboo forests, eventually altering the micro-environmental conditions in the forest floor. Field observations and communications with the villagers confirmed that the study sites are prone to recurrent forest fires especially during the extended dry season, suggesting fire as the main contributory factor to high mortality rates in bamboo forests in these native forests.

\section{CONCLUSIONS}

The results conclude that $B$. bambos show the potential to alter the structure and composition of moist evergreen forests in Sri Lanka. The bamboo-driven alterations of micro-habitat conditions could to be the main driving force accountable for structural and compositional changes over time. Also, the bamboo-driven impacts are highly diverse among study sites, suggesting that the impacts may vary depending on the onsite vegetation and physical characteristics. The findings also highlight the importance of more comprehensive studies to evaluate long-term impacts of B. bambos. Bamboos always attract less critics 
as their commercial values most of the time override their ecological consequences. However, their potential threats cannot be ignored completely. Thus, knowledge on potential consequences of weedy native species such as $B$. bambos and their underlying mechanisms are critical in order to introduce effective measures to curtail probable impacts on these highly vulnerable ecosystems.

\section{ACKOLWEDGEMENTS}

The authors wish to acknowledge the National Research Council, Sri Lanka for providing financial assistance to conduct this research project (Grant No. NRC 16/054).

\section{DECLERATION OF CONFLICT OF INTEREST}

Authors declare no conflict of interest.

\section{REFERENCES}

Ashton, P.S. and Gunatilleke, C.V.S. (1987). New light on the plant geography of Ceylon I. Historical Plant Geography.Journal of Biogeography 14: 249-285.

Bai, S., Wang, Y., Conant, R.T., Zhou, G., Xu, Y., Wang, N. and Chen, J. (2016). Can native clonal moso bamboo encroach on adjacent natural forest without human intervention? Scientific Reports, 6 (July), 31504. Available at https://doi.org/10.1038/srep31504.

Buckingham, K., Jepson, P., Wu, L., Ramanuja Rao IV, Jiang, S., Liese, W., Lou, Y. and Fu, M. (2011). The Potential of Bamboo is Constrained by Outmoded Policy Frames. AMBIO 40: 544-548.

CABI (2020). Bambusa bambos. In: Invasive Species Compendium. Wallingford, UK: CAB International. www.cabi.org/isc.

Caccia, F.D., Chaneton, E.J. and Kitzberger, T. (2009). Direct and indirect effects of understorey bamboo shape regeneration niches in a mixed temperate forest. Oecologia 161(4): 171-180.

Canavan, S., Kumschick, S., Le Roux, J.J., Richardson, D.M. and Wilson, J.R.U. (2019). Does origin determine environmental impacts? Not for bamboos. Plants People Planet 1: 119-128.

Canavan, S., Richardson, D.M., Visser, V., Le Rouxm J.J., Vorontsova, M.S. and Wilson, J.R.U. (2017). The global distribution of bamboos: assessing correlates of introduction and invasion. AoB PLANTS 9: plw078; doi:10.1093/aobpla/plw078.

Carey, M.P., Sanderson, B.L., Barnas, K.A. and Olden, J.D. (2012). Native invaders-challenges for science, management, policy and society. Frontiers in Ecology and the Environment 10: 373-381.

Castro, W., Salimon, C.I., Medeiros, H., Da Silva, I.B., and Silveira, M. (2013). Bamboo abundance, edge effects, and tree mortality in a forest fragment in southwestern amazonia. Scientia Forestalis/Forest Sciences, 41(98): $159-164$

Connell, J.H. (1978). Diversity in tropical rain forests and coral reefs. Science 199: 1302-1310.

Duriyaprapan, S. and Jansen, P.C.M. (1995). Bambusa bambos (L.) Voss. In: Dransfield S, Widjaja EA, eds, Plant Resources of South-East Asia No. 7. Bamboos. Leiden, Netherlands; Backhuyes: 56-60.
Dutta, K. and Reddy, C.S. (2016). Geospatial analysis of Reed Bamboo (Ochlandra travancorica) invasion in Western Ghats, India. Journal of the Indian Society of Remote Sensing 44: 699-711.

Fox, J.W. (2013). The intermediate disturbance hypothesis should be abandoned. Trends in Ecology and Evolution 28: $86-92$

Garrot, R.A., White, P.J. and White, C.A.V. (1993). Overabundance: an issue for conservation biologists? Conservation Biology 7(4): 946-949.

Gonzalez, M.E., Veblen, T.T., Donoso, C. and Valeria, L. (2002). Tree regeneration responses in a lowland Nothofagus-dominated forest after bamboo dieback in South-Central Chile. Plant Ecology 161: 59-73.

Griscom, B.W., Ashton, P.M.S. (2006). A self-perpetuating bamboo disturbance cycle in a neotropical forest. Journal of Tropical Ecology 22(5): 587-597.

Griscom, B.W. and Ashton, P.M.S. (2013). Bamboo control of forest succession: Guadua sarcocarpa in Southeastern Peru. Forest Ecology and Management, 175(1-3): 445454.

Gunatilleke, N., Pethiyagoda, R. and Gunatilleke, S. (2008). Biodiversity of Sri Lanka, Journal of National Science Foundation Sri Lanka, Specieal Issue 36: 25-62.

Hulme, P.E. (2007). Biological invasions in Europe: drivers, pressures, states, impacts and responses. In: Hester R, Harrison RM, editors. Biodiversity under Threat. Cambridge: Cambridge University Press; pp. 56-80.

Hufbauer, R.A. and Torchin, M.E. (2008). Integrating ecological and evolutionary theory of biological invasions. In: Nentwig W. (Ed.), Biological Invasions. Berlin, Germany: Springer.

IFAS. (2014). Assessment of non-native plants in Florida's natural areas: Bambusa bambos. Gainesville, Florida, USA: University of Florida. http://assessment.ifas.ufl. edu/assess ments/bambusa-bambos/

IUCN Sri Lanka and Ministry of Environment and Natural Resources (2007). The 2007 Red List of Threatened Fauna and Flora of Sri Lanka. Colombo, Sri Lanka. xiii+148pp.

Kang, W., Tian, C., Kang, D., Wang, M., Li, Y., Wang, X. and Li, J. (2015). Effects of gap microsites and bamboo on Abiesfaxoniana regeneration in a subalpine forest, China. Journal of Plant Interactions 10(1): 59-64.

Kobayashi, T., Saito, A. and Hori, Y. (1999). Species diversity of the understory dominated by dwarf-bamboo Pleioblastus chino Makino ina secondary forest with different numbers of years after the lastmowing. Journal of the Japanese Society of RevegetationTechnology 24: 201-207.

Kudo, G., Amagai, Y., Hoshino, B. and Kaneko, M. (2011). Invasion of dwarfbamboo into alpine snow-meadows in northern Japan: patternof expansion and impact on species diversity. Ecology and Evolution 1: 85-96.

Larpkern, P. (2005). Bamboos : great benefits for people but a possible threat to plant communities. (College of Bodhivijjalaya, Srinakharinwirot University). Available at http://bodhi.swu.ac.th/pdf/66/panadda.pdf.

Laurance, W. and Ferreira, L. (1998). Rain forest fragmentation and the dynamics of Amazonian tree 
communities. Ecology 79(6): 2032-2040. https://doi. org/10.2307/176707

Laurance, W.F., Delamonica, P., Laurance, S.G., Vasconcelos, H.L. and Lovejoy, T.E. (2000). Conservation: rain forest fragmentation kills big trees. Nature 404: 836-836.

Ledo, A. and Schnitzer, S.A. (2014). Disturbance and clonal production determine liana distribution and maintain liana diversity in a tropical forest. Ecology 95(8): 2169-2178.

Levine, J.M., Adler, P.B. and Yelenik, S.G. (2004). A metaanalysis of biotic resistance to exotic plant invasions. Ecology Letters 7: 975-989. http://doi.org/10.1111/ j.1461-0248.2004.00657.x.

Lima, R.A.F., Rother, D.C., Muler, A.E., Lepsch, I.F. and Rodrigues RR. (2012). Bamboo overabundance alters forest structure and dynamics in the Atlantic Forest hotspot. Biological Conservation 147(1): 32-39. https:// doi.org/10.1016/j.biocon.2012.01.015

Maranho, A.S. and Salimon, C.I. (2015). Maranthaceae overabundance decreases richness and abundance of regenerating woody plants in natural gaps. Neotropical Biology and Conservation 10(2): 53-62.

Medeiros, H., Castro, W., Salmon, .CI., Silva, I.B. and Silveira, M. (2013). Tree mortality, recruitment and growth in a bamboo dominated forest fragment in southwestern Amazonia, Brazil. Biota Neotropica 13(2): 29-34.

Molino, J.F. and Sabatier, D. (2001). Tree diversity in tropical rain forests: a validation of the intermediate disturbance hypothesis. Science 294: 1702- 1704.

Ohrnberger, D. (1999) The bamboos of the world: annotated nomenclature and literature of the species and the higher and lower taxa. Elsevier, Amsterdam, p 585.

Okutomi, K., Shinoda, S. and Fukuda, H.K. (1996). Causal analysis of the invasion of broad-leaved forest by bamboo in Japan. Journal of Vegetation Science 7(5): 723-728. https://doi.org/10.2307/3236383.

Oliveira, A.C.A. (2000). Efeitos do bambu Guadua weberbaueri Pilger sobre a fisionomia e estrutura de uma floresta no sudoeste da Amazonia. Dissertacao de mestrado, Instituto Nacional de Pesquisa na Amazonia. Universidade do Amazonas, Manaus.

Panabokke, C.R. (1996). Soils and agro-ecological environment of Sri Lanka. Natural Resource Series No.2.pp220.Natural Resource Energy \& Science Authority. Colombo, Sri Lanka.

Perera, G.A.D. (2012). Ecology of Sri Lankan Dry Forests: Implications for the Conservation Management of Northernmost Dry Forests, Proceedings of Jaffna University International Research Conference (JUICE-2012), published: March 2014, Sri Lanka, pp. 263-269.

Prematilleke, K.P., Madawala Weerasinghe, S., and Weerawardene, N.D.R. (2015). Biodiversity survey on Meethirigala Forest Reserve with special reference to the invasion of Ochlandra stridula. The Sri Lanka Forester Volume 36-37: 25-40.

Rayle, C.M., Franklin, S.B. and Lu, Z. (2015). Fire Occurrence in Relation to Bamboo Dominance in the Qinling Mountains of china: Evidence From Phytolith and Charcoal Records in Holocene Sediments. Science China Earth Science 58(7): Available Online 2015, 58(100795), 1-10. https://doi.org/10.1007/s11430-0155060-3.

Richardson, D.M., Pyšek, P., Rejmánek, M., Barbour, M.G., Panetta, F.D. and West, C.J. (2000). Naturalization and invasion of alien plants: concepts and definitions. Diversity and Distributions; 6: 93-107.

Rother, D.C., Rodrigues, R.R. and Pizo, M.A.(2009). Effects of bamboo stands on seed rain and seed limitation in a rainforest. Forest Ecology and Management, 257(3): 885-892. https://doi.org/10.1016/j.foreco.2008.10.022.

Rother, D.C., Rodrigues, R.R. and Pizo, M.A. (2016). Bamboo thickets alter the demographic structure of Euterpe edulis population: a keystone, threatened palm species of the Atlantic forest. Acta Oecologica 70: 96102.

Sarojam, N. and Kumar, M.S.M. (2001). BAMBUSA BAMBOS (L.) VOSS, KFRI Consultancy Report 1 (Part 1). Kerala Forest Research Institute, Kerala, India.Available at http://www.bicindia.org/site_media/ publications/bambusa001.pdf.

Silveira, M. (1999). Ecological aspects of bamboodominated forest in southwestern Amazonia: an ethnoscience perspective. Ecotropica 5: 213-216.

Silveira, M.(2005). AFlorestaaberta combambu no sudoeste da Amazonia.Padroes e processosemmultiplasescalas. ADUFAC, Rio Branco.

Somasekeram, T., Perera, L.A.G., Perer,a M.P., De Silva, B.G., Karunanayake, M.M. and Epitawatta, D.S. (1988). National Atlas, Survey Department, Colombo.

Space, J.C. and Flynn, T. (2000). Observations on invasive plant species in American Samoa. Honolulu, HI: USDA Forest Service, Pacific Southwest Research Station, Institute of Pacific Islands Forestry.

Suzuki, S. (2015). Chronological location analyses of giant bamboo (Phyllostachys pubescens) groves and their invasive expansion in a satoyama landscape area, western Japan. Plant Species Biology 30: 63-71.

Tokuoka, Y., Ohigashi, K., Watanabe, K., Yamaguchi, H., Ara, T. and Nakagoshi, N. (2015). Removal of competitive native species combined with tree planting can accelerate the initial afforestation process: an experiment in an old field in Japan invaded by dwarf bamboo and kudzu. Journal of Forestry Research 26: 581-588.

Valery, L., Fritz, H. and Lefeuvre, J.C. (2013). Another call for the end of invasion biology. Oikos 122: 1143-1146.

Vilà, M., Basnou, C., Pyšek, P, et al. (2009). How well do we understand the impacts of alien species on ecological services? A pan-European cross-taxa assessment. Frontiers in Ecology and the Environment; 8: $135-144$.

Von Holle, B., Delcourt, H.R. and Simberloff, D. (2003). The importance of biological inertia in plant community resistance to invasion. Journal of Vegetation Science, 14: 425-432. Available at https://doi.org/10.1658/11009233(2003)014[0425:tiobii]2.0.co;2

Wang, G. and Liu, F. (2011). The influence of gap creation on the regeneration of Pinus tabuliformis planted forest and its role in the near-natural cultivation 
strategy for planted forest management. Forest Ecology \& Management 262(3): 413-423. http://dx.doi. org/10.1016/j.foreco.2011.04.007.

Yang, Q.P., Yang, G.Y., Song, Q.N., Shi, J.M,. Ouyan,g M., Qi, H.Y. and Fang, X.M. (2015). Ecological studies on bamboo expansion: process, consequences and mechanism. Chinese Journal of Plant Ecology 39:110124.

Zhao, H., Peng, S., Wu, J., Xiao, H. and Chen, B. (2008). Allelopathic potential of native plants on invasive plant Mikania micrantha HBK in South China. Allelopathy Journal 22(1): 189-196.

Zhang, C., Zou, C.J., Peltola, H., Wang, K.Y. and Xu, W.D. (2013). The effects of gap size and age on natural regeneration of Picea mongolica in the semi-arid region of northern China. New Forests 44: 297-210. 